\title{
Letters
}

\section{Ethical medical practice and the NHS}

\section{SIR}

I enjoyed the paper by Persaud about ethical medical practice and health service organisation (1). The author chronicles some of the ethical disadvantages of the American system. However, he mistakenly equates the health service reforms with an American-style system. This is wrong, because the internal market envisaged by the health service reforms is quite different from the mainly insurancebased systems in the United States. The provider incentives are not as sharp with the British system, where the treatment of patients can produce a departmental surplus for reinvestment in patient services. Contrast this with the American system, or indeed other systems with fee-for-service provisions where the sharpened incentive of personal profit results in overprovision. Over-provision cannot be expected to occur at the same level in the reformed health service. At the same time, by moving away from the command economy of medicine, staff are at least given the incentive to create thriving clinical departments. Thus, the health service reforms represent the ideal compromise between stultifying central planning (characterising Communist health services and the NHS before the reforms) and market failure endemic to all systems with feefor-item-of-service methods of doctor imbursement.

Furthermore, your author has completely missed one of the further ethical advantages of the reforms. This pertains to the fact that consultations with individual consultants need no longer be the determining factor in access to services. Purchasers will now decide how resources should be spent and who is eligible and who is not. This, in my view, is greatly preferable, since it removes the bargaining component of many consultations and allows hospital doctors to return to their traditional role as advocates for the patients they treat.

\section{Reference}

(1) Persaud R D. What future for ethical medical practice in the new National Health Service? Fournal of medical ethics 1991; 17: 10-18.

RICHARD J LILFORD

Professor of Obstetrics and Gynaecology, The University of Leeds, St Fames's University Hospital, Leeds, LS9 $7 T F$

\section{Ethics of using Nazi research}

SIR

Stephen G Post argued recently for a duty not to use data of Nazi experiments (1); his argument is made even stronger considering the fact that the 'data' from these experiments are scientifically worthless.

Examinations of the results of Nazi experiments revealed critical deficiencies in scientific method even by the standards of the 1940s (2). For example, during the infamous hypothermia experiments at Dachau, data were faked by the prisoners responsible for recording the measurements (3). Similar evidence was revealed in Joseph Mengele's study of heterochromia (4). Sigmund Rascher's work on high altitude and hypothermia done at Dachau was rejected by three different German universities when he tried to submit it to fulfil the requirement for a higher doctorate degree (5). Given the fact that the work was rejected by at least one German expert who was later sentenced to death by the Nuremberg Tribunal for his own medical crimes, it is doubtful whether ethical considerations were the reason for these decisions.

In light of the above, any use or presentation of 'data' from the Nazi experiments as scientific facts is unethical.

\section{References}

(1) Post S G. The echo of Nuremberg: Nazi data and ethics. Fournal of medical ethics 1991 ; 17: 42-44.

(2) Berger R L. Nazi science - the Dachau hypothermia experiments. New England journal of medicine 1990; 322: 1435-1440.

(3) Neff W. Report on his experiences. Nuremberg Tribunal ND 908 Sheet 60 .

(4) Lifton $\mathrm{R}$ J. The Nazi doctors: medical killing and the psychology of genocide. New York: Basic Books, 1986: 362.

(5) Reinhardt O. The 'Nazi doctors' debate. Medical journal of Australia 1990; 153: 645-647.

GERSHON B GRUNFELD, PhD Department of Medical Humanities Southern Illinois University, School of Medicine, PO Box 19230 , Springfield, Illinois 62794-9230,

USA

\section{Ethics of preventive medicine}

\section{SIR}

Your article by Petr Skrabanek (1) is based on a confusion. He argues that somehow preventive medicine among populations is exempt from the constraints of ethical guidelines, while in contrast therapeutic medicine among individuals is constrained by strict ethical guidelines. But in fact it is experimentation that is governed by such guidelines. Thus experiments among individuals reliably to assess the therapeutic efficacy of drugs or treatments are thus constrained, as are 
experiments among groups to assess the prophylactic efficacy of promotional intervention.

Only when practitioners know the answer, or can persuade themselves that they know the answer, can these constraints be dispensed with. It is here where the true paradox lies, not in Skrabanek's confused distinction. To think one knows the outcome consequent upon applying any intervention is sufficient to absolve professionals from a formal duty to inform, to counsel and to obtain consent. Clearly such a paradox amounts to a double standard which simultaneously provides a disincentive to enquire.

The true state of knowledge concerned with a particular question will be fixed at a given time, but the certainty or doubts of individual practitioners may not be. Thus certain practitioners can proceed without constraint while the uncertain ones cannot.

It may well be true that in clinical therapeutic medicine people prefer certainty (whether entirely scientifically justified or not) more than they might in prophylactic medicine, for obvious reasons to do with urgency, specificity and often, desperation. But there is no reason to suppose that the nature and extent of these uncertainties are any different between the two. (See for instance (2).)

Skrabanek argues that there are many uncertainties in the practice of preventive medicine, which are not deemed to be uncertain by some practitioners. He is right. But it is nonsense to argue that this makes preventive medicine special in some important sense and it is certainly not thus exempted from these, rather peculiar, ethical constraints.
References

(1) Skrabanek P. Why is preventive medicine exempted from ethical constraints? Fournal of medical ethics 1990; 4: 187-190.

(2) McPherson K. International differences in medical care practices. Health care financing review. US Dept of Health and Human Services annual supplement, 1989.

KLIM MCPHERSON Health Promotion Sciences Unit, Department of Public Health and Policy, London School of Hygiene and Tropical Medicine, University of London, Keppel Street, London WCIE 7HT

\section{Donors and sellers of organs}

SIR

In your issue of September 1990, $\mathrm{J}$ Harvey argues for schemes for nonexploitative paid kidney donation. He claims that such schemes might end the shortage of kidneys available for transplant.

I would like (1) to point out a significant element of confusion in the terms of his proposal, (2) to outline the main reason for the present shortage, and (3) to propose a policy which would do far more to end shortages in the supply of all the organs and tissues which can be transplanted.

(1) In the New Collins Concise English Dictionary, 'donor' is defined as 'any person who gives blood, organs, etc, for use in the treatment of another person'. 'Give' is defined as 'to present or deliver voluntarily to another', and 'sell' as 'to dispose of or transfer to a purchaser in exchange for money'.

So those who give blood or organs are donors; those who sell them are sellers, and not donors of any kind. So the phrases 'paid donations' and 'paid donors' are oxymorons; the phrases 'unpaid donations' and 'voluntary donors' are tautologies.

(2) The present shortage of organs available for transplant indeed produces a vast amount of unnecessary suffering and a large number of wholly preventable deaths.

Why the shortage? Because countries presently rely on individual donation as the means of providing healthy organ and tissues to patients needing treatment. So large numbers of healthy organs and tissues critically needed by patients are being destroyed. Donor cards are not enough.

(3) What we need is a system whereby healthy organs and tissues would be routinely saved from cadavers, with legal protections for those persons who wish to dissent. Healthy organs and tissues would be presumed available for transplant unless there was express objection. Th appropriate national health authoritie would still be obliged to dispose o bodies in a decent and seemly way after death, but they would also be require to save any organs and tissues which could be used to save life or to restore vital bodily functions.

We must abandon the failed policy based on the desirability of donation and adopt a policy based on the duty of salvation. This would do more than any alternatives to help end the curren worldwide shortage of available organ and tissues.

WILLIAM PODMORE, MA, ALA 14 Wilton Way, Dalston, London E8 $3 E E$ 